\title{
УЏБЕНИК КОЈИ ПОМЕРА ГРАНИЦЕ НАСТАВЕ СРПСКОГ ЈЕЗИКА
}

- Први мултимедијални уџбенички комплет намењен учењу српског језика у дијаспори -

(Марина Јањић, Српски - језик мога завичаја, Академска српска асоцијација, Ниш, 2020)

Методика наставе српског као завичајног језика последњих неколико година код нас постаје предмет интезивнијих проучавања - организују се научни скупови, пишу монографије и чланци о статусу и очувању српског језика у дијаспори. Пажња се усмерава на решавање теоријско-методолошких питања јер је реч о релативно младој научној дисциплини која се на српском говорном тлу развија паралелно са успостављањем центара за учење српског језика као страног. Ова нова глотодидактичка област представља огранак методике наставе српског као страног, али се издваја као самосвојна област посвећена извођењу наставе српског језика у дијаспори, а намењена је превасходно новим генерацијама многобројних српских исељеника. Она је резултат наше нове демографске слике коју деценијама уназад карактеришу емиграциона кретања према економски развијеним деловима света (Европи, Америци, Африци, Азији). Поражавајући је податак да је у расејању број српских исељеника једнак броју Срба који живе у матици (дакле, око шест милиона наших људи живи у иностранству). У циљу очувања њиховог националног идентитета јавља се потреба за учењем и неговањем језика земље свог порекла, остављеног завичаја, нарочито код млађих генерација (друге и треће) наше емиграције које се полако, али сигурно, асимилују са домицилним становништвом земље у којој одрастају. Стога је настава српског језика као завичајног од огромног националног значаја за све оне који желе да одржавају везе са земљом матицом.

Ипак, баш као и у настави српског језика као страног, приметно је непостојање уџбеничког комплета којим би се обезбедила успешна реализација наставе. Да проблем буде још већи, захтеви које савремена школа поставља пред наставу српског као завичајног јесте објављивање електронских интерактивних уџбеника. Најпотпуније интересовање за решавање најважнијих теоријско-методолошких питања показала је 
Марина Јањић, редовни професор Филозофског факултета у Нишу, објавивши, најпре, Методику наставе српског као завичајног језика, а затим и први електронски интерактивни уџбенички комплет за реализацију овог вида наставе: Српски - језик мога завичаја.

Уџбенички комплет Српски - језик мога завичаја садржи три уџбеника поетских назива (Кад си срећан!, О, радосне вести!, Подигни глас!) и са правом се може тврдити да је реч о уџбеничком комплету који поставља нове стандарде у савременом издаваштву. У сва три уџбеника коришћени су иновативни приступи, односно најсавременије методе и технике захваљујући којима се обезбеђује успешан развој свих језичких компетенција, односно остваривање постављених наставних циљева на сва три нивоа учења језика - почетном, средњем и напредном. Његовом квалитету доприносе пажљиво бирани садржаји, упечатљив дизајн, те умешно педагошко-психолошко и дидактичко-методичко обликовање. Посебно је интересантно да у овом уџбеничком комплету не постоје помоћне јединице (радна свеска, озвучени уџбеник, флеш-картице), својствене, на пример, уџбеничким комплетима у настави српског језика као матерњег. Разлог таквом опредељењу јесте полифункционалност трију уџбеника који у себе укључују све остале ,традиционалне” јединице уџбеничког комплета.

Садржаји у уџбеничком комплету су диференцирани према нивоу. У првом уџбенику, Кад си срећан!, обрађују се садржаји почетног нивоа учења српског језика; у другом, О радосне вести!, они садржаји који су прописани на средњем нивоу, а у трећем, Подигни глас!, налазе се садржаји примерени напредном нивоу. Вишегодишњи рад у настави и искуство у објављивању уџбеника аутору је помогло да садржаје прилагоди деци до четрнаест година, поштујући начела систематичности и поступности, свесне активности, очигледности и, нарочито, принципа завичајности. Уз то, коришћена је најсавременија наставна методологија, захваљујући којој уџбеници обезбеђују развој и учвршћивање језичких компетенција, али и стваралачког и критичког мишљења. Садржаји у овим уџбеницима подељени су на лекције насловљене тако да одсликавају теме које се у њима обрађују: Моја Србија, Упознавање, Моја породииа, Доме, слатки доме, Хајде да се играмо, Свет боја, Доба дана, Бројеви, У иколи, Нова година, Дани у недељи, Годишња доба, Саобраћај, Кућни љубимич, Рођендан, Осећаға (почетни ниво); Приче моје баке, Свуда пођи, кући дођи, Моја лепа Србија, Човек који је изумео ХХ век, Манастир Ђурђеви ступови, Стакларева љубав, Временска прогноза, Боковић улази у историју, Божић, Аска и вук, Ценовник, Хајдуци, Орање Марка Краљевића, Капетан Цон Пиплфокс, Златибор (средњи ниво); Подигни глас, Грозд тежак стотине килограма, Први српски пи- 
саи, Моја отацбина, Крсна слава, Плашко Храбровић узвраћа ударащ, Шешир професора Косте Вујића, Вечити дерби, Кад књиге буду у моди, Милутин Миланковић, Копаоник, Плава звезда, Дечак и пас, Песмо моја, Орлови рано лете (напредни ниво). Свака тема (домовина, породица, свакодневни живот, празници, прославе, наука, спорт, књижевност, географија итд.) обрађује се уз помоћ лингвометодичких предложака захваљујући којима се ствара реални животни контекст у коме се српски језик користи. Другим речима, свака лекција је упакована у прозрачни оквир српске душе. Поштујући препоруке дате у Заједничком европском оквиру за учење језика, аутор користи аутентичне наставне материјале како би на најбољи могући начин представио савремени српски језик и тековине историје и културе српскога народа. Управо културна историја и савремена стварност у снажном међусобном устројству чине оквир за учење језика: са једне стране, културни миље делује мотивационо на учење завичајног језика, а са друге стране, напредовање у језику омогућава боље упознавање живота у Србији: њене историје (манастир Ђурђеви ступови, Свети Сава), географије (Златибор, Смедерево, Копаоник), етнографије (текстови о Божићу, о крсној слави); њених научника (Николе Тесле, Милутина Миланковића), спортиста (Новака Ђоковића); уметничких остварења, ауторске књижевности (песме Јована Јовановића Змаја, Драгана Лукића, Драгана Лаковића, Душка Радовића, Љубивоја Ршумовића, Алексе Шантића, Пеђе Трајковића, Мирослава Антића, Десанке Максимовић; приче, бајке и одломке из романа Гроздане Олујић, Ива Андрића, Бранислава Нушића, Милована Витезовића, Данила Киша, Бранка Ћопића) и народне књижевности (легенде о Светом Сави, пословице, брзалице, епске песме Орање Марка Краљевића, Цар Лазар се приволева цуарству небеском). Оваква сазнања буде у ученицима национални понос и љубав према завичају, земљи порекла, а тиме и жељу да се врате коренима и боље их упознају. Такође, идући од теме до теме, лекције се усложњавају, како у погледу тежине материјала који се у њима представља тако и у погледу структуре и броја одељака који се са уоченом правилношћу појављују: лингвометодички предложак, граматика, речник, говорна вежба, писмена вежба, слушање, занимљивости, белешке, питањь, радни налози и задаци. Неизоставан одељак сваке лекције у уџбеницима чине граматички садржаји који су истумачени на стручан, али и примерен начин у складу са потребама и могућностима ученика на сва три нивоа у учењу језика. Поштујући принцип завичајности, ауторка настоји да ученике упозна са граматиком у контексту српске културе. Тако, захваљујући технчким могућностима мултимедије, неизоставни део сваке лекције представља емитовање најразличитијих сценских остварења из света филма, музике, ТВ-емисија, екранизованих драма за децу, Ев- 
ровизије, и то: трејлери филмова (Орлови рано лете); одломци из видеоснимака позоришне представе и радио-драме (Капетан Џон Пиплфокс); инсерти из ТВ-емисија за децу забавног и дидактичког карактера (Плава птица, Плашко Храбровић узвраћа удараи), аудио-записи песама наших познатих извођача за децу као што су Драган Лаковић, Бранко Коцкица, хор Колибри (Деца су украс света, Браћу не доносе роде, Ми се не бојимо, учимо да бројимо, Санке Деда Мраза, Данас нам је диван дан, Кад си срећан; Иили смо у Африку, Београде, Београде), песме родољубиве (химна Боже правде, Србијо, најлепша бајко) и световне садржине (Обновимо себе, подигнимо Ступове, Маријо, дели бела кумријо, О, радосне вести, Звезда се засја, Расти, расти, мој зелени боре, химна Светом Сави), популарне дечје песме са Евросонга (Подигни глас у извођењу Дарије Врачевић), чиме се на функционалан начин користе аудио и видео материјали у настави. Захваљујући томе остварује се, с једне стране, дубинска (унтрашња и спољшња) мотивација за учење српског као завичајног, а са друге потпуна интеракција између уџбеника (наставника) и ученика. Са овим електронским интерактивним уџбеницима који „певају, свирају, глуме...” ученици постају живи и интезивно активни чинилац наставе, чак и на удаљености од више хиљада километара.

Мултимедијални уџбеници, еквивалентно могућностима које пружају учесницима у настави, захтевају изузетну стручност тимова и то, осим неоспорне и доминантне улоге самог аутора, графичких дизајнера и програмера (у развоју софтвера). Уџбенике је према ауторовој замисли графички дизајнирала др Јефимија Лакић, професор Уметничког факултета у Нишу. Захваљујући томе, ови мултимедијални уџбеници својим колоритом и живописношћу мотивишуће делују на ученике, активирајући сва њихова чула - уџбеници се чују, гледају, ,додирују” (захваљујући техничким могућностима да се на виртуелним страницма може писати, цртати, бојити, спајати, повезивати). Боје се користе, осим за диференцирање садржаја према нивоима, и за представљање основних елемената дизајна који остварују своје номиналне функције - садржајни блок за представљање градива, навигациони елементи и трака са алатима за једноставнију оријентацију у самим лекцијама, односно избор жељених садржаја. Од прве до последње стране свих уџбеника уочава се доследност у њиховом представљању. Доминантно место припада висококвалитетним и „живим” покретним фотографијама (тзв. слајдшоу), илустрацијама и иконицама чији је задатак функционално презентовање садржаја, формулисање задатака и, самим тим, мисаоно ангажовање ученика. Њима се придружују рачунарске анимације и специјални графички ефекти којима се градиво представља на прегледан, динамичан, атрактиван и занимљив начин: прикази који се покрећу (слајдови српских гра- 
дова, планина и природних лепота), текстови који лебде, цртани карактери који трепћу, активација покрета и звука кликом, емитовање видео и аудио формата итд. Управо ефикасни начини представљања градива јесу највећи квалитет дидактичко-методичког обликовања уџбеника који у том погледу представљају праве тродимензионалне мултимедијалне уџбенике. Тим софтверске компаније ИТЦ из Ниша на челу са др Славимиром Стошовићем, професором Високе техничке школе из Ниша, креирао је захтевну вишеслојну апаратуру, при чијој изради су коришћени разноврсни и комплексни алгоритми. Једном речи, ученик се уз помоћ најразноврснијих метода, техника и поступака креће кроз садржаје трију уџбеника.

Посебну атрактивоност ових мултимедијалних уџбеника представљају његове својеврсне маскоте: Милица и Милан. Визуелно, они су другарски пар, девојчица и дечак из школске клупе (не без разлога носе типична српска имена), а заправо симболизују персонификацију уџбеника, те из лекције у лекцију, од почетка до краја ученике „воде” до нових сазнања, дају објашњења, постављају питања, износе своје ставове и уверења о темама које се обрађују у лекцијама. Веома је упечатљиво да Милица и Милан „одрастају” заједно са својим другарима, ученицима из дијаспоре, тј. у складу са напредовањем у усвајању градива, из једног нивоа у нови напредни ниво, еволуирају од деце до тинејџера, што се на симболичан начин доводи у везу са образовним и емоционалним сазревањем ученика. Ту је и велики број анимација, фотографија, илустрација и табеларних приказа које се користе за дефинисање стручних (граматичких) термина, визуелизацију садржаја, односно формулисање питања, радних налога и задатака. Методичку апаратуру карактерише разноврсност - осим стандардних форми сарадничких императива (заокруживање, допуњавање, повезивање), у уџбеницима се користе и оне којима се од ученика очекује да певају, глуме, рецитују, играју игре (Лети, лети... птица), затим налози да нешто цртају или обоје, да пишу, подвлаче, али и да преслушају звучне и видео записе, погледају инсерте из телевизијских серијала, емисија, позоришних представа и филмова за децу. У свакој лекцији методичка апаратура осмишљена је тако да развија четири језичке вештине: слушање са разумевањем, читање, писање и говор. Комуникативна метода је превасходно утемељена присуством обавезне говорне или писмене вежбе у складу са темом лекције. Такође, аудио и видео материјали, снимљени од стране професионалних читача и глумаца, доприносе развоју језичких вештина кроз активно укључивање ученика у наставу. Другим речима, од ученика се често очекује да преслуша аудио-запис или погледа видео, а затим да̂ одговор на постављено питање. Они се захваљујући уџбенику играју, глуме, снимају, спремају 
колаче, певају, гледају „живе” разгледнице из Србије, учећи поступно српски језик и упознајући културу. Свака лекција почев од средине првог уџбеника, садржи обавезан део посвећен граматици српског језика. Притом, инструкциони језик је јасан и прецизан, а секвенце интеграције градива омогућавају успостављање хоризонталне и вертикалне корелације са садржајима у самом уџбенику и међу уџбеницима.

Уџбенички комплет Српски - језик мога завичаја, аутора Марине Јањић, представља значајан подухват у модернизацији и популаризацији наставе српског језика уопште, а посебно, када је реч о настави српског као завичајног, немерљив је значај ових уџбеника у погледу њеног утемељења. Реч је о уџбеничком комплету који успешно одговара на све захтеве савременог издаваштва. Његова полифункционална природа ће омогућити да се настава српског језика прилагоди потребама и очекивањима ученика у XXI веку, али и утицати на промену начина размишљања о функционалности електронских интерактивних наставних средстава. Учећи српски уз помоћ овог уџбеничког комплета, ученици у дијаспори ће неосетно, али на забаван и динамичан начин, усвојити разноврсне садржаје из области духовне и материјалне културе земље својих предака. И оно што је најважније, овим се уџбеницима руши не само културолошка, већ и физичка баријера између деце наше емиграције и наших наставника, те могућност модерног учења на даљину постаје мост који спаја просторе удаљене хиљадама миља, а потомке наше дијаспоре са домовином својих предака. Овај мост их, макар и симболично, враћа завичају, те је овај електронски интерактивни уџбенички комплет не само од несумњивог огромног значаја за предметну дициплину већ добија огроман родољубиви карактер и несумњиву националну важност.

\author{
Александар М. Новаковић ${ }^{8}$ \\ Универзитет у Нишу \\ Филозофски факултет \\ Департман за србистику
}

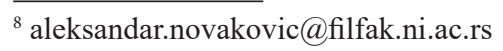

